\title{
SOME METHODOLOGICAL PRINCIPLES OF THE ARCHITECTURAL ENVIRONMENT'S OBJECTS DESIGN
}

\section{NIEKTÓRE ZASADY METODOLOGICZNE PROJEKTOWANIA OBIEKTÓW ŚRODOWISKA ARCHITEKTONICZNEGO}

DOI: $10.30540 /$ sae-2020-011

\begin{abstract}
A b s tract
The article discusses the methodological principles of typology and design of architectural environment's objects with the analysis of its system-structural foundations. According to them, hierarchical levels of formation and stages of environmental systems and objects' design are revealed with some examples of author's designs. The research is based on systemic and environmental approaches that make it possible to view the architectural environment's objects as hierarchically subordinate.
\end{abstract}

Keywords: architectural environment's objects, typology, design, systemic-structural principles, hierarchical levels

\section{Streszczenie}

$W$ artykule omówiono metodyczne zasady typologii i projektowania obiektów środowiska architektonicznego z analiza jego systemowo-strukturalnych podstaw. Zgodnie z nimi hierarchiczne poziomy formowania $i$ etapy projektowania systemów i obiektów środowiskowych ujawniaja się z niektórymi przykładami projektów autora. Badania opieraja się na podejściach systemowych i środowiskowych, które umożliwiają oglądanie obiektów środowiska architektonicznego jako hierarchicznie podporządkowanych.

Slowa kluczowe: obiekty środowiska architektonicznego, typologia, projektowanie, zasady systemowo-strukturalne, poziomy hierarchiczne

\section{INTRODUCTION}

The various urban development objects and the existing method of their design are determined by the typology of the architectural environment, which consists of spatial and subject features of the environment state and, in fact, most of this state itself (atmosphere of environment), that exist in the conceptual unity and integrity. Into the basis of the study of characteristics and parameters of certain typological order the main criterion must be assigned - the leading dominant feature. The concepts of environment like residential, industrial, recreational, urban environment, etc., determine its functional features and purpose, determined by the types of human activity.

A variety of research studies have been dedicated to the issues of typology of environment [1-9].
These and other authors, relying on the concept of a systematic approach considering environment as an architectural integrity of conditions of the material world of human, that changes in transition from one system level to another.

In a system approach, the core of which is to implement the requirements of general theory of systems, the object of research is a set of interrelated elements and components that make up a system, linking the components of the overall objective.

\section{THE MAIN PART}

Modern dynamic changes of various factors and conditions of formation of architectural environment, diversity and versatility of environmental systems and objects and approaches to their typology and design 
cause the need to clarify the understanding of the quality of the environment and the methodological foundations of its creation in design activities.

It is noted that, depending on the problems that the architect-designer are facing, there are four levels of environmental design: micro level (object-spatial), mezo level (spatial), macro level (architectural planning), mega level (planning). At each level of environmental design, we can distinguish the types of architectural environment that will vary by properties of the material components; by lifestyles and situations of residents' life; by features of environmental philosophy and concepts of the people who created it; by the principles and mechanisms of development [4].

Along with the fact that most authors believe the functional and spatial parameters or architectural environment are primary while creating typological classifications, it is also classified by figured characteristics, morphological characteristics, sociocultural values, etc.

Among the recent researches doctoral dissertation, in which the principles of multilevelness, socioorientation, awareness and integration are proposed, is based on the construction of a typology of architectural environment [5].

Despite the relevance of certain classifications of understanding the qualities of architectural environment and its compositional and spatial organization for the architectural design lies in the plane of open (exterior) space with no cover or roof and indoor - the interior space. These forms of environment differ by the degree of openness to the natural environment, but the same function to be resolved with quite different artistic and compositional means. Hereinafter this typological distribution should be differentiated into the open and closed subsystems respective, also to be divided into smaller-scale elements. Moreover, each element of the system or subsystem should be considered as a complete system a certain level.

The main statements of the theory of architectural environment systems organization are:

- the system of architectural environment is not the simple sum of the individual elements of building development and landscape fragments, but the single holistic unit;

- as a holistic unit, architecture system has certain boundaries that separate its territory from the external environment;

- every architecture system (the interior, the building, the area, the city, etc.) consists of a number of subsystems, which are also divided into smallerscale items;

- the stability of system (immutability of its components in its vital activity) is determined by internal regulation, which is implemented through forward and backward linkages;

- every element of the system can be considered as a complete system of the second level of organization of matter;

- systems are distributed into the open systems, if they exchange information and energy with the external environment, selectively open systems and closed (locked) systems when this exchange and interaction does not occur; architectural systems belong to the selectively open for exchange with the environment, due to the human factor [7].
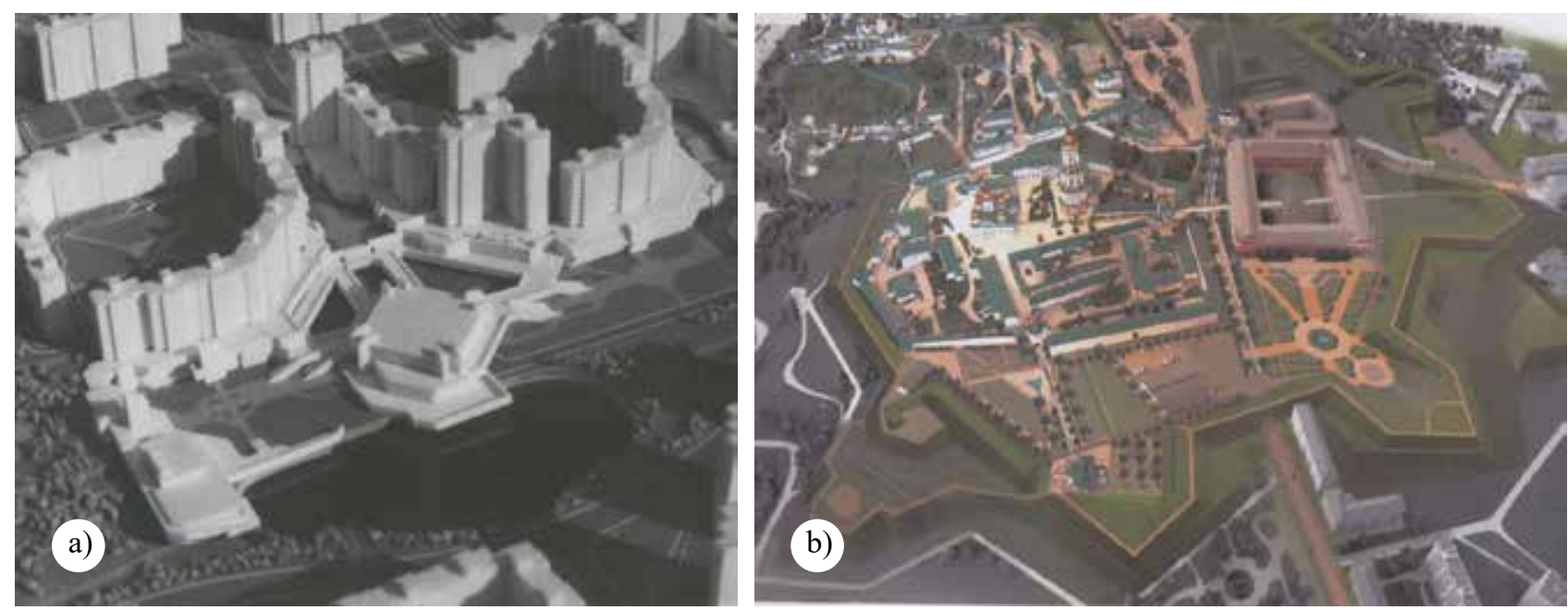

Fig. 1. Open spaces of architectural environment on the level of the projects of development of districts, neighborhoods, urban housing and public entities and ensembles: a) residential and public area in the city of Kyiv - architect Vadym Abyzov (in the group of authors); b) the historic area with recreation spaces adjacent to the National Historic and Cultural Preserve "Kyivo-Pecherska Lavra" - architect Vadym Abyzov (in the group of authors) 
The first hierarchical level of open spaces of architectural systems is the urban development structural unit that defines the place and the role of environmental facility in the settlement area and its development under various natural and climatic conditions and urban location, characteristics of the surrounding natural and artificial environments.

Urban development conditions of design units' location, together with the natural and geographical factors play a crucial initial role in the formation of both open and closed (interior) spaces of environment. And this hierarchical level has several structural sub levels or subsystems: the first level - general scheme (conception) of settlement of the country and planning of its territory (the concept of territorial development) considering placing the country in the European urban space; the second level - regional planning (planning regional territories); the third level - city master plan; the fourth level - projects of development of districts, neighbourhoods, urban housing and public entities and ensembles with relevant improvement of streets and squares (Fig. 1).

Regarding the formation of streets and squares, it is worth to pay attention that especially important this problem becomes in the historic cities of Europe that have a significant historical and cultural heritage and at the same time are the centres of countries, regions and districts with their business and commercial activity. In this case it is important to create a full urban environment by creating pedestrian and recreational zones, taking into account the socio-economic, urban, environmental, engineering, aesthetic and other factors and requirements. Renovation, regeneration, reconstruction and development of the historic part of the city with the creation of aesthetically valuable environment depends on the overall creative idea and concept of development of the central city area, matching its spatial and compositional structure to the design of functional processes and environments and provide the special recreational environment with unique multifaceted sound (Fig. 1b).

Along with the functions of recreation and cultural and community service, pedestrian zone is a place of cultural events like meetings, town fairs, exhibitions, festivals, theatre and sporting performances, but also for daily meetings and communication between people in shopping malls, restaurants, cafes, etc. At the same time urban environment areas have complex zoning caused by the number of different functions that they formed by. Multi-colouring and polycentrism become an important feature of these objects, that combine transport arteries, various buildings, structures and systems, sometimes planted area, gardens and frequently, in terms of historical development, monuments of cultural heritage $[1,8,9]$.

The next hierarchical level of open space design is the level of organization of the environment of individual buildings and structures, subordinated to the respective urban formation and environment in general (Fig. 2). At this level, the following organizational subsystems can also be distinguished: defining the basic functional structure of an urban development object in the context of the overall environmental concept; its compositional and spatial organization, colour and lighting solutions, including some functional components.
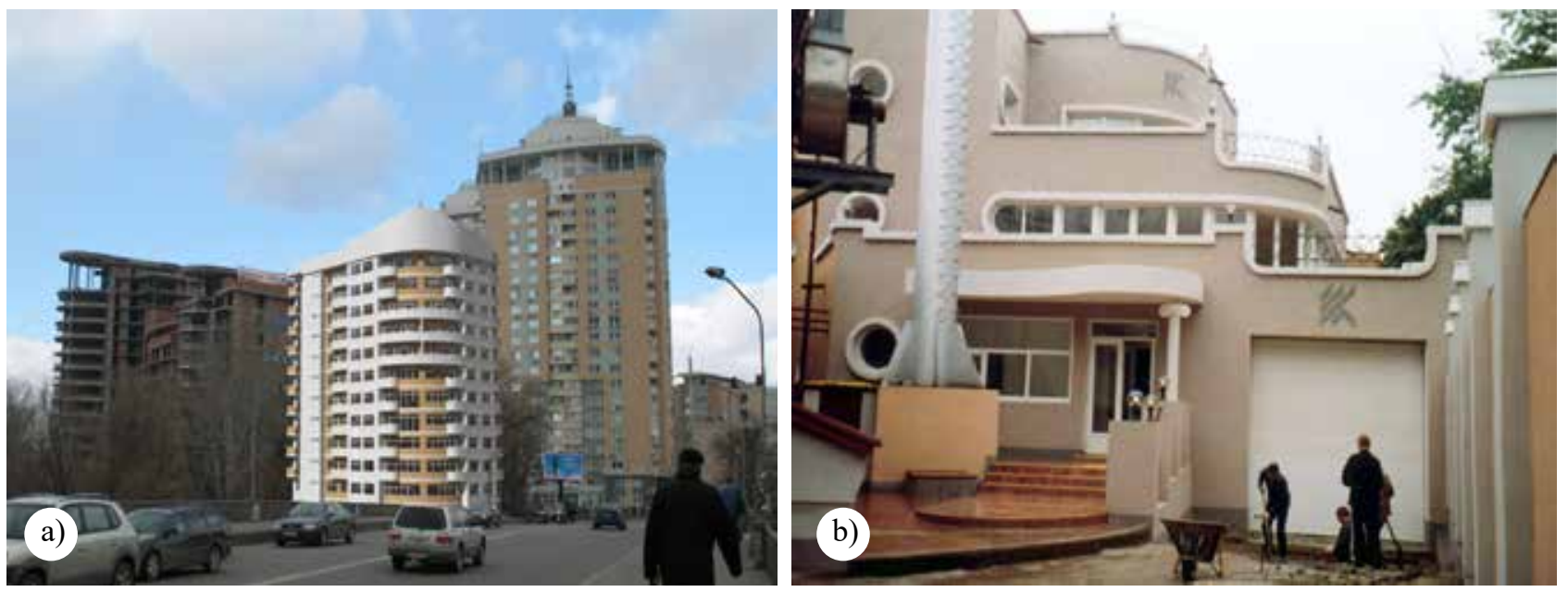

Fig. 2. Open spaces of architectural environment on the level of the individual buildings and structures: a) residential building - architect Vadym Abyzov; b) public building in Kyiv-architect Vadym Abyzov 

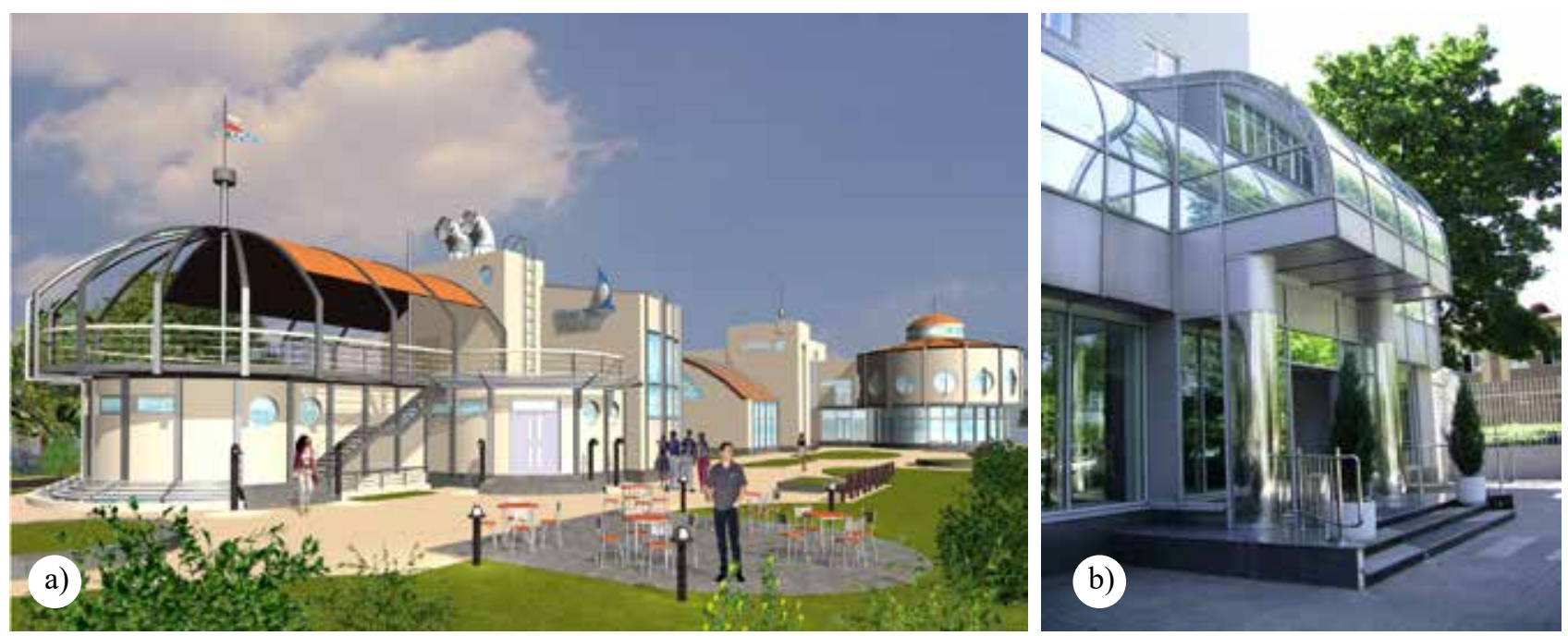

Fig. 3. Open spaces of architectural environment on the level of the territorial and spatial fragments, surrounding the buildings: a) design of the recreation and entertainment complex in the town of Brovary, Kyiv region - architect Vadym Abyzov; b) design of the office building's entrance group in Kiev - architect Vadym Abyzov

The last structural block is the recreational environment of territorial and spatial fragments, surrounding the buildings, such as a variety of nearground areas (e.g. relaxing and active recreation), entrance groups, outdoor terraces, exploited roofs, atriums, etc. (Fig. 3). In this case, this hierarchical level already has the subsystem of separate original structural elements such as specific elements of landscaping and improvement, small architectural forms, visual information facilities, various temporary and mobile devices, etc. For example, for an entrance group, it is envisaged a substantive filling of its environment and artistic and figurative solution of the main system-forming elements and fragments, synthesis of the design of the entrance group with decorativeapplied, visual and landscape art; use of appropriate construction materials and products (Fig. 3a).

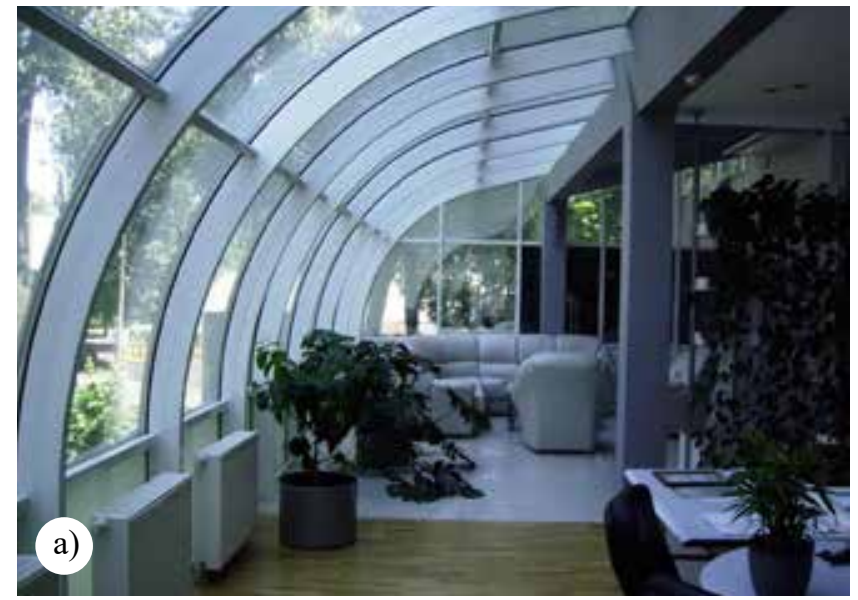

As for the indoor (interior) spaces, they should also be divided into the corresponding hierarchical levels of architectural environment.

The first hierarchical level of indoor recreation spaces is to organize the internal environment of a building or ensemble of buildings, aggregating the complex with a single interior space. At this level, the overall design and spatial composition concept and ideology of the architectural environment of the entire interior space, the conditions of its relationship and interaction with the open space of the environment are solved.

The second hierarchical level of indoor spaces will be the organization of the internal environment of specific functional facilities inside the different types of buildings or complexes, taking into account the connection with other open and closed elements

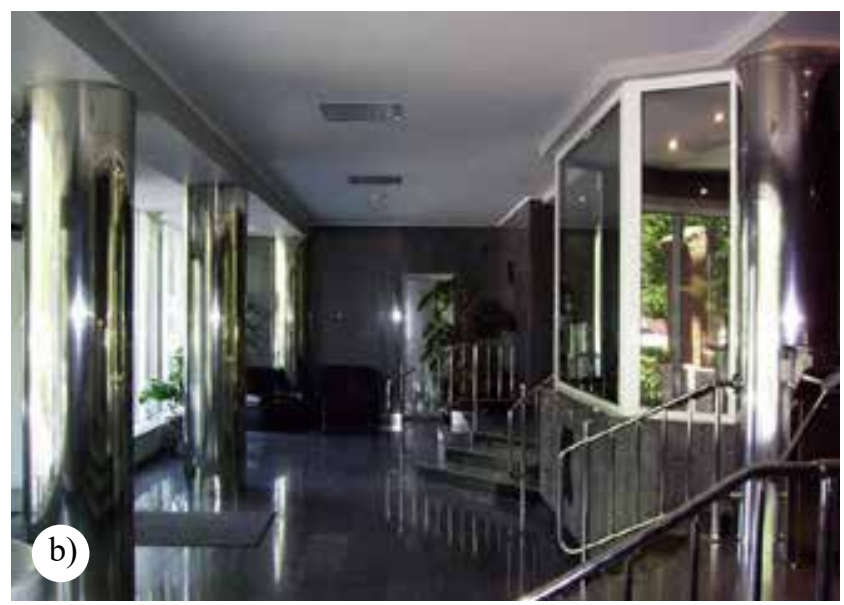

Fig. 4. Inner spaces of the specific architectural environment inside the different types of buildings or complexes: a), b) interior of public buildings in Kyiv-architect Vadym Abyzov 
of the environment. At this level, as well as at previous, functional zoning, architectural and spatial composition, overall colour solution is determined, not the total inner space of the building or complex, but a separate facility or rooms (Fig. 4).

The third structural unit is the subject content of the environment and the compositional and artisticimaginative solution of the main system-forming elements and fragments of the interior of a particular room in the context of its general environmental design.

The elements of the subject content of the architectural environment primarily include its equipment, which has a functional purpose, such as furniture, visual advertising, equipment, small architectural forms, elements of engineering infrastructure. Artistic design of equipment, along with the need for a comprehensive solution of specific functional, structural, ergonomic, economic conditions of the environment must meet the aesthetic requirements that will reflect a certain style of environment. So the design of furniture, flower beds, fountains, sculptural installations, lamps, etc. should be designed according to the general conceptual design. The saturation of the composition and the creation of the stylistic expressiveness of objects is also due to the expressive details of decor and the synthesis of arts. Therefore, the fourth hierarchical level will be an aesthetic solution of the details of decor and synthesis of arts. Harmonious synthesis of design objects with fine and applied arts (artistic ceramics, monumental and decorative painting, artistic textiles, sculptural compositions, consumer goods made of wood, metal, glass, etc.) is a powerful means of their organic interaction and connection with the architectural environment. Here one should also remember about the skilful use of the means of landscape art and phyto design. After all, plants, herbs and flowers and their meaningful and aesthetic combinations are of great importance in the arrangement of the entertainment environment.

Finally, the use of appropriate building materials and products is a separate level for both indoor and outdoor spaces. Skilful use of traditional building materials (stone, ceramic, wood) and their texture provides special natural artisticfigurative characteristics of the environment. The high development of scientific and technological progress and the introduction of nanotechnologies reveals broad aesthetic and artistic features, along with traditional, innovative products and materials (concrete and reinforced concrete, anodized metal, glass and other materials and products from mineral melts, polymer and recycled materials) for the creation of extraordinary environmental compositions and implementation daring creative design ideas. At the same time, it is important to ensure the stylistic integrity of the spatial and artistic-figurative solutions of the complex.

\section{CONCLUSION}

The system-structural principles of typology and design of environmental objects provided in this article are important for proper understanding of the phenomenon of architectural environment as a system and can be used more effectively for further research and creation of various concepts and models. The proposed systematic and environmental approach will help to improve the architectural environment's objects organization, accurately determine the requirements and conditions of their formation and implementation at different hierarchical levels, and can be useful for both theory and practice of design.

\section{REFERENCES}

[1] Abyzov V., Modern Conditions and the Impacts of the Creation of Architectural Environment, "Materials Science \& Engineering - IOP", Published on line: in volume 245 World Multidisciplinary Civil Engineering-ArchitectureUrban Planning Symposium - WMCAUS 12-16 June 2017, Prague, Czech Republic. Published online: 4 November, Bristol, 2017.

[2] de Botton A., The Architecture of Happiness, Penguin UK, 2007

[3] Millennium Ecosystem Assessment, 2005, Ecosystems and human well-being: Synthesis, Island Press, Washington, DC, Accessed March 2013 (https://www.epa.gov/enviroatlas/enviroatlas-benefit-category-recreation-culture-andaesthetics).

[4] Timohin V., Shebek N., Malik T., etc., Fundamentals of Design architectural environment. Textbook . - Kyiv: Base, 2010.

[5] Shebek N., Theoretical basis of harmonization of architectural environment, Abstract. Dis. on the paper of sciences degree doctor of Architecture, Kyiv, KNUBA, 2013.

[6] Kamionka L. Architektura zharmonizowana z otoczeniem - aspekt wybranych metod oceniajacych. The architecture of the harmonized with the environment - aspect of the selected evaluation methods [in:] Architektura zharmonizowana 
w przestrzeni miasta [in:] Harmonized architecture in the city space. Monografia, Architektura 4, Politechnika Świętokrzyska, Kielce 2016, s. 21-29.

[7] Panova L., Systematic of architectural environment. Kharkiv, HNAGH, 2010.

[8] Shimko V., Architectural Design of the urban environment. Textbook, Moscow: „Architecture-C”, 2006.

[9] Gehl J., Życie między budynkami, Wydawnictwo RAM, Kraków 2009.

\section{Acknowledgments:}

The work was financed by the Kiev National University of Technology and Design

\section{Podziękowania:}

Praca była finansowana przez Kijowski Narodowy Uniwersytet Technologii i Projektowania 